\title{
Literary (creative nonfiction) docu-memoir: a different way of writing a life
}

\author{
Jo Parnell
}

University of Newcastle, Australia

\section{ABSTRACT}

Pioneered by the British writer Tony Parker, literary docu-memoir is a rare form that involves the creative nonfiction writer interviewing and audio-taping ordinary people for their unusual life experience as the resource material for a literary production. In everyday conversation, people use a language of their own making to make sense of their experiences for themselves and the person they are talking to. The literary docu-memoir brings out a deeper level of meaning in the speech and the reflections of ordinary people as elicited by the docu-memoirist.

In this paper I offer a working definition, and discuss how I evolved the form adapted from that of Parker to fit my own work on care leavers. There are urgent ethical issues in relation to making public distressing episodes from the subjects' lives, and for the writer in relation to readers. In a fictionalised documentary, how does the writer make clear where the boundary lies between fiction and fact, and verbatim and edited testimony? There are also literary questions: How much should the researcher appear in the narrative? How to use the powerful raw material, and recreate the subject's experience, in a way that readers can access the essence of that experience?

In this paper, I will discuss, and attempt to tease out, the key aspects of the type of literary docu-memoir in which I am interested, and as I use it in my own work, understanding that other definitions may be proposed. ${ }^{1}$

Keywords: literary docu-memoir, new form, first-person writing, writing lives, personal histories, affective states. 


\section{FORM AND WORKING DEFINITION-WHAT IT IS AND IS NOT}

Literary docu-memoir is a rare form of life writing which involves the writer interviewing and audio-taping ordinary people for their unusual life experience and thoughts and feelings, as the resource material for a literary work of creative nonfiction. Caroline Forché and Philip Gerard define creative nonfiction as factual writing that is "infused with the stylistic devices" of the "best fiction and the most lyrical of narrative poetry", and which has a fidelity to "truthfulness"; it is "storytelling of a very high order-through the revelation of character and [...] the subtle braiding of themes, rhythms and resonance [...] precise and original language", and a distinctive narrative stance; "its very literariness distinguishes this writing from deadline reportage" and "daily journalism" (Forché and Gerard 2001, 1-2). Unlike fiction writers, creative nonfiction writers cannot work from imagination and memory alone (Cheney 2001, 196). Literary docu-memoir involves the writer interviewing, researching deeply, and immersing themself in the subjects' lives. Theodore A. Rees Cheney advises that "the highly involved research effort" requires that the writer be willing to "conduct their research out in the real world", to "move in on the lives of complete strangers and to dig deep into those lives", and also willing to "stick with a story" for weeks, months, even years (Cheney 2001, 196).

Literary docu-memoir is not the same as "documentary memoir", which is an unusual creative approach that can be used variously in nonfiction works. One definition of documentary memoir is implicit in an article by Loni Ding about the making of her documentary film series Ancestors in the America (1997): "Our visual method [...] tells stories from the viewpoint of the [...] subjects themselves; it is a way of combining research history with fictive storytelling. [...] we are finding ways to create a first-person voice using historical and cultural materials in which the personal accounts and experiences of Asians in America are conspicuously absent" (Ding 1998, 1). The aim was to give an insight into what the subjects "thought or tried to do for themselves in response to the opportunities and obstacles they encountered" in their life in America (Ding 1998, 1). To recreate these stories the film-makers searched for archaeological sites, artefacts, Asian folklore, and "conventional primary documents such as census records, legislative reports, and period newspaper clippings", and "framed these remains of a once robust presence, with the critical analyses of on-camera specialists and scholars" (Ding 1998, 1).

A literary parallel to Ding's film would be Dianne Wilson's The Spirit Car: journey to a Dakota past, (2006). The publishers describe the book as "documentary-memoir", an "exquisite counterpoint of memoir and 
carefully researched fiction" that "vividly illuminates the difficult history of the Dakota people" (Wilson 2006, n.p.). In her author's note, Wilson explains her work: "The stories in Book One are based on real people whose lives have been reimagined [...] I wanted to bring the facts alive", to transform history "into a living, breathing reality"; the stories in Book Two are a mixture of memoir, family stories, and pure invention, but readers "can trust the information in these stories [....] The letters I quoted are real, all of the people existed, and I visited each place that I wrote about" (Wilson 2006, xi). As well, Wilson audio-recorded her family's stories and first-hand accounts of their past experiences as Dakota Indians with mixed heritage as a resource for her book. In crafting, Wilson "imagined conversations and feelings based on plausible assumptions and the intuitive understanding" which she "gained of these people after burrowing inside their lives" (Wilson 2006, xii).

Ding and Wilson both employ the fiction writer's techniques of authorial omniscience to imaginatively explore the experiences of ethnic groups from the viewpoint of the subjects themselves. Ding situates the subjects in relation to the socio-political climate of an eighteenth and nineteenth century America in which the European population held political power. Wilson does likewise, but the time period of her work extends from the 1800 s into the present day. The documentary memoir approach departs from what I mean by literary docu-memoir.

Pioneered by the British writer Tony Parker, the literary documemoir blurs the boundaries between life writing and life narrative, and straddles literary memoir and literary documentary. The memoir component is primarily that of the subject. The writer does not tell or explain the subject's story, rather creates a literary space in which to introduce the subject to the reader. Literary docu-memoir uses first person, and is written in such a way that the subject speaks for them self about her or his experience. Unlike biography, ${ }^{2}$ in literary docu-memoir matters of time and timing do matter; the subject is living at the time of writing-the death of the subject is definitive even though the work may be published posthumously. The documentary component can take the form of illustrations, and images such as photographs and documents inserted by the writer to lend credence to the text. The documentary component can also be factual elements which the subject mentions naturally in conversation about her or his experience, and which produces a documentary-type effect in the subject's narrative on a personal and affective level.

The literary docu-memoir is a specialised form of writing that demands the writer's use of creative empathy. The writer who employs creative empathy aspires to be as non-judgemental of the subjects as possible, and to write with reflection. This involves the writer using immersion 
research techniques to gain a sympathetic understanding of the subject's story in order to show the reader what it is like to have led an unusual life. This also depends on the ability of the writer to feel empathy with the subject and convey that in writing in order to share with the reader another person's feelings or emotional experiences as if they were her or his own. ${ }^{3}$ Alfred Margulies notes the psychiatrist's dilemma in providing descriptors for the subtleties and extraordinary nuances in the various in-between states or complex amalgams of some other's emotional experiences: "in our attempts to feel into another person's" emotional experience "we come up against our inherent limitations of language and meaning" (Margulies 1993, 181-182). This could equally apply to the writer. Words are the writer's sole tool to convey others' complex and subtle affective states through creative empathy.

Literary docu-memoir is a mixture of fact, lyricism and story. Being a form of creative nonfiction, it permits the writer's use of some novelistic techniques. Sondra Perl and Mimi Schwartz argue that even though "the world of creative nonfiction is not invented" the "reality is mediated and narrativized": "the particular subjectivities of authors are crucial and should be textually embodied" because "language and form must have a surface and texture that remind readers that the work is artificed", because, by its nature, creative nonfiction is "not reserved for a narrow specialist audiences" rather aimed at the general reader (Perl and Schwartz 2006, 4-7). The further implication for literary docu-memoir is that to best convey a sense of the subject's experience the writer must choose which threads to follow from the wealth of detail granted in audio-taped interviews. Memoirists, and so literary docu-memoirists, are bound by a strict code of ethics that novelists are not. G. Thomas Couser (2012) posits that ethical dangers for memoir stem from the fact that it is "rooted in the real world and therefore makes certain kinds of truth claims", and while "utter fidelity to truth" is neither possible nor desirable in such work, the writer assumes "two distinct kinds of obligations", one to the biographical and historical record, and one to the people they depict" (Couser 2012, 10).

Literary docu-memoir of the type in which I am interested, exists in a liminal space. It lies in the interstices of oral and social history, and life narrative and life-writing, and crosses boundaries into other disciplines such as, for instance, psychology and sociology, and also incorporates elements of survivor narrative, trauma narrative and witnessing. But it is different from all those forms by the fact that it is essentially a work of literary memoir. Moreover, the creative approach to the crafting of the oral narratives, while maintaining their integrity, distinguishes the literary docu-memoir from other forms with which it might be confused. In 
my view, it is the author's positioning in the writing of the literary documemoir that is crucial in defining this area of creative nonfiction.

\section{PARKER-THE PIONEER}

In an interview, Parker revealed that he was a convinced socialist, atheist and pacifist, and that he never wanted to be a writer (Thompson 1994, 64-73). In his desire to help fight against what he saw as social injustice, he became a volunteer prison visitor. He had a chance meeting with a $\mathrm{BBC}$ radio producer and that led to a broadcast of his tape-recorded interview with a serial offender, and to being asked if he would write a book about the prisoner. Parker wrote the book, his first, and every book thereafter using the method taught to him by the radio producer: "Take the questions out, and try to make it into a consecutive piece" (Thompson 1994, 65). Parker seems to be the first creative nonfiction writer of literary works to craft his books entirely from extended interview material from which he edited out most of his interview questions.

Lyn Smith reveals that Parker's aims in interviewing were "always directed at producing books forged from the interview material", and he never interviewed people for any other reason (Smith "Only Listen ..."1999, 244). All Parker's twenty-two works, written in the mid part of the twentieth century, deal with persons and communities who are isolated and marginalised-most notably, with prisoners. Parker saw his writing as a way to give people and communities on the margins of society a voice (Smith “Only Listen ...” 1999, 247). Parker's stated purpose in writing was to show the ordinary man in the street to the ordinary man in the street. Margery Parker once said about her husband, "His dream was $[\ldots]$ that if people listened to these [others] and saw them as real human beings and not stereotypes, it would somehow help a more liberal and understanding attitude develop towards them" (qtd. in Smith "Only Listen ..." 1999, 253).

When Parker sat down to write, he transcribed the interviews and waited to see what theme would emerge. Parker explained, "I always regarded myself as a blackboard for people to write on. And see what they write on it" (Thompson 1994, 67). Asked if when dealing with a community rather than a single informant he saw the problem of editing to be different, Parker replied, "Yes. Because you've always got to think, 'What gives this unity?' ... the individual, or the place", and he named Lighthouse (1975) as an example of a successful work (Thompson 1994, 67). To research for Lighthouse, Parker lived amongst the lighthouse community and stayed out on the various lighthouses with the lighthouse keepers. 
Lighthouse is mostly crafted as a series of interviews and conversations that begin with brief but vivid introductory descriptions of the individual informants. These short passages place the informants in their homes or places of work (lighthouses), and so provide an ordinary and "normal" setting for the interviews. ${ }^{4}$ These introductions do not employ an "I". One could see this as Parker's attempt to draw the reader's focus to the subject. In Lighthouse, his (Parker's) is mostly an "unseen" presence; nevertheless, the visiting writer-interviewer to the lighthouse community is subtly evident throughout the book. ${ }^{5}$ For the main part, the writer's presence is only implied through the informants' conversations. Parker also demonstrates his use of creative empathy through the informants' conversations. The various members of the community understand what others in the community are going through, and empathise with each other generally. ${ }^{6}$

As a mark of gratitude to his informants, Parker gave them his assurance that their privacy would be protected (Thompson 1994; Smith "Only Listen...” 1999). In line with his stated aims in writing, Parker wrote Lighthouse to open a closed community to public view to dispel possible misconceptions on the part of the reader. The book is written in such a way that the reader is encouraged by the text to believe that what they are reading is the actual in every detail. But at the end of the work in the acknowledgements Parker tells the reader that because of his personal promise to his informants, he masks their identities and all other identifying factors. He called his method "composing". ${ }^{7}$ The lighthouses in Lighthouse are composites of the actual, and the informants are also composites of the real, and, writes Parker, "Additionally, the interviews themselves are composites of conversations with different people, transcribed from tape-recordings. But this is what was said; and I hope it conveys some impression of the world of those in the lighthouse service" (Lighthouse 1975, 288). These sudden revelations highlight elemental flaws within the narrative. By framing the work as authentic and faithful to the truth when it is in fact a construction based on composites, Parker somewhat fictionalises a work that is supposedly nonfiction to the point where he possibly strays beyond the bounds of ethics for nonfiction (and creative nonfiction) writers. Parker's methods create problems for the integrity of the voice because what was said by an informant could have been equally "said" by other people. In this sense Parker honours the contract with his subject, but breaks the contract between the writer and reader. For Parker, these ethical concerns were not a consideration. ${ }^{8}$ Rather his concerns were less academic. In relation to the informants, Parker "was looking for the essence of each person and to give them the opportunity to express this essence" (Smith "only Listen..." 1999, 247). In relation to the 
readers, Parker's aim was to capture the essence of life in the lighthouse community in a work that was both enjoyable and informative for the "ordinary everyday reader." ${ }^{9}$ Smith writes: Parker "had no role model; his style was entirely his own invention" (Smith "Only Listen ...” 1999, 250). Ultimately, all Parker's works are experiments with his invention of a new way of writing that can be called literary docu-memoir.

\section{EVOLVING THE FORM}

I now turn to my own work, and begin with an explanation of my focus on the experiences of the Forgotten Australians.

This group of care-leavers, of whom I am one, are of mainly Anglo-Celtic heritage. Like the Australian Indigenous children of the Stolen Generation and the so-called British and Maltese Child Migrants (the Forgotten Children), they spent part or all their childhood in foster care or Children's Homes in Australia sometime during the mid-part of the twentieth century. As children, nearly all these people suffered severe hardship and horrific psychological, physical and sexual abuse that was unprecedented, and felt the effects of displacement. With the Forgotten Australians, as with care-leavers who were in orphanages in England, displacement was mainly socially motivated. As children, these people were denied a voice, and that is still something of the case today. There are many thousands of Forgotten Australians, but for various reasons not many write, or even tell, their stories. A very few would like their stories to be known, but feel that they lack the ability to write their memoirs to publication. Several of these people asked if I might write their personal stories in a literary work and tell their stories "true". The problem for me as a creative nonfiction writer was how to approach the task ethically, how to stay true to the facts to honour my contract with the reader, and also with the subjects whose personal stories would be made public in a literary work.

My supervisor at the time, now my mentor, suggested that one way in which I could approach the task would be to write a literary docu-memoir. I decided to try and evolve the form pioneered by Parker, and tailor it to fit my work on the care-leavers. My subject focus dictated that my perspective and treatment would be necessarily different to that of Parker.

Before I could begin, because I was dealing with living people, I needed Ethics Approval. The Ethics Committee required that I write Participant Information Statements and Consent Forms tailored to my potential participants. After receiving signed consent forms from the potential participants, and taking a lesson from Parker, to help make these participants feel more at ease I arranged to interview them in places of their choosing. 
During the interview process, two things happened. One: each of the participants freely said on tape that they were only speaking with me because I was a writer and also a Forgotten Australian who had been through similar experiences to their own. They said they felt that I would understand them, and could be entrusted to present their stories. This made me very aware of possible power-positions and ethical boundaries. Two: at one point in each of the interview sessions, suddenly the participant's eyes seemed to go so clear that I felt that I was looking deep down into her or his very soul and I instinctively knew that what I was getting from the participant was trust, and what I was hearing was a fullness of her or his thoughts and feelings. For me, this was an awe-inspiring experience. Nothing was said, but from that point on, the participant seemed to forget the tape-recorder and appeared to hold nothing back. When crafting my book I knew for certain that I could not possibly disclose to the reader everything that had been said in the interviews, even though said on tape. I had to be vigilant that I include nothing that could betray any participant's trust in me, and also decipher the meanings in their words as truly as is possible. To tell too much in a literary work could very well prove intimidating for the reader. These people's experiences were indeed very shocking, and even more traumatic than I have revealed in my book. So to best convey a sense of the subjects' experiences, I tried to choose which threads to follow from the wealth of detail granted in the interviews, and to write just enough to inform potential readers and satisfy my subjects that I was telling their stories "true". Even so, some critics might question as to whether I tell too much. My answer is that as a Forgotten Australian who has spoken with many other Forgotten Australians, not to reveal the truths of their stories would be condescension and betrayal, and to once again humiliate these people and deny them a voice.

As Couser (2004) warns, there are ethical dangers inherent in writing the lives of others. One such danger is misleading the reader, and another is misrepresentation of the subject. Couser gives John G. Neihardt's Black Elk Speaks as one example of both these dangers. ${ }^{10}$ Julia Watson and Sidonie Smith (2010) cite Black Elk Speaks as an example of the as-told-tonarrative - one process of collaborative life narrative (Smith and Watson 2010, 264-265). Another process is the ghost-written narrative of a celebrity, and yet another is a "coproduced or collectively produced narrative in which individual speakers are not specified or in which one speaker is identified as the representative of a group" (Smith and Watson 2010, 264-265). All three processes of collaborative life narrative run ethical dangers through being altered. Quite often they are subjected to being multiply mediated by "two or more parties" included in "the production of the published story" (Smith and Watson 2010, 265). 
I do not see the people who appear in my work as the vulnerable subjects of whom Couser speaks ${ }^{11}$ or literary docu-memoir as a work of collaborative life narrative so defined by Smith and Watson. The subjects in my work are not diseased or disabled, and do not suffer some other anomalies, and they are not culturally, racially, or ethnically different from the society in which they live. Nor are they celebrities, or a tribe or a collective, and they do not rely on a translator, and are not represented by one chosen speaker. They each speak for themselves as they wish. They are ordinary people who live ordinary lives, private individuals who are undifferentiated in their society. They are marginalised only by dint of being persons with a history of having survived a particularly traumatic childhood, but most of these people do not know or know of each other. The only two people involved in the actual interview sessions were the researcher-interviewer-writer (me), and the participant. These interviews were conducted on an equal footing and with mutual respect. Moreover, all the participants were fully informed before the commencement of the project as to what the project involved. All these people demonstrated that they were intelligent adults well able to understand the project's purpose and of making their own decisions, and gave their informed consent of their own free will to participating in the project.

I suppose that when writing lives it is virtually impossible to eliminate the ethical dangers inherent in the form altogether, but to try and minimise those risks, after I transcribed the interview-tapes word for word I forwarded these transcripts to the individual subjects for their approval before commencing the more creative work. Later, I awaited their approval with the draft chapters before proceeding further. Also, each of the subjects is informed that their interview tapes will remain their property, and been promised a copy of the final work if and when it is published. As well, in my book, I fully inform potential readers about my intentions, purposes, and methods of writing upfront in the Introduction to the work, and also in the text. Even so, Couser's findings have ramifications for a literary docu-memoir on the Forgotten Australians. This is partly because this is a story which has not been previously told from inside the ranks of the Forgotten Australians in a literary work aimed at the general reader, and could seem to provide a very influential depiction of an overlooked people within the Australian society, and about which virtually nothing has been previously known.

In my project, five of the participants are Forgotten Australians, and two are not. Of these two, one is Bev, the recently discovered sister of Geoff, a Forgotten Australian who is a subject in the work. Both Bev and Geoff were adopted out as babies. Neither knew of the other's existence until late in middle life. I included Bev's story in my book in an attempt 
to show what it feels like for her to be the newly discovered sibling of a Forgotten Australian. Even though these stories involve a brother and sister who were adopted out as babies, the focus of this work is on careleavers and not adoptees. The term Forgotten Australian does not apply to adoptees because, generally speaking, adoptees are not people who were "forgotten" as children, and they are not care-leavers as such other than in exceptional circumstances when that child may have been placed in a Children's Home or orphanage sometime after adoption as happened with Geoff. Mick is the other subject in the work who is not a Forgotten Australian. Born and raised in England where he spent part of his childhood in an orphanage, Mick is now a naturalised Australian. I included Mick's story because he is a care-leaver, and I felt that his story might serve to show that the effects on the lives of the children who were incarcerated in orphanages in both Australia and England were similar despite the geographical distances between the two countries. Of course, these people's stories also may have similarity with those of others in various parts of the world. The type of childhood that the Forgotten Australians and Mick suffered may very well be, in one way, a universal story of abused childhood. In some parts of the world Children's Homes and orphanages still exist, and all over the world the abuse and usage of children still takes place on an everyday basis.

To begin with, like Parker, other than to determine the focus of my work, I did not plot a theme for each of the subjects' stories. I could not. I did not know what any of my subjects would have to say about their life experience, I did not know their personal "truths". During the audiotaped conversations, like Parker, I saw myself as a blackboard for the subjects to write on, and waited to see what themes would emerge from out of the wealth of material gathered in the interviews. In ordinary conversation people use a language of their own making when trying to make sense of their experiences for themselves and the person they are talking to. As I see it, literary docu-memoir goes further to also give the subjects the opportunity to express their deeper feelings about their experiences. For example, in ordinary life and also in his taped conversations, and so in my book, Mick describes himself as an ordinary person, but because the taped conversations are intended solely as resource material for a literary production Mick has been given a specific context in which to discuss his experience. As a result, Mick freely expresses himself in a way that he most likely would not do in ordinary everyday conversation, and this enables him to come to terms with his demons. In his taped conversations Mick takes a philosophical slant. He observes that sometimes in life bad things just happen, and that reflection can bring a form of resolution, and then voices his childhood experience as the source of his 
bouts of depression. I feel that Mick rewrites his experience in a way that could allow the reader to gain a sense of Mick's experience and hopefully empathise, In his interview, and so in my book, Mick states: "So my reality is all I've got and it's made me what I am and I figure I could be a lot worse, but with people like us ... you have to accept you'll always have that monkey on your back. You can't throw it off because it'll just jump straight back on ... so you've got to learn to try and carry it with dignity".

Like Parker, I situate my subjects in the ordinary world, in their actual homes and towns, as they go about living their daily lives. In my attempt to bring the subjects into three-dimensional life for the reader I try to have both them, and others in the smaller stories, move and speak as ordinary people both within, and outside of, the interview situation. It is my belief that writing of this type allows readers to identify with the subjects, and also allows the subjects as care-leavers a literary space in which to claim a sense of identity. Differently to Parker and his persona in Lighthouse, I openly include myself in my book as a lead into the work, and I include myself as a part of the action, as the writer, researcher, and observer in an attempt to provide a framing reference and a setting for the stories and lend credibility to the work as a whole.

I begin my book with my true story of my traumatic childhood, and I begin the subjects' stories with my true experience of battling floods to gather these stories, and end with an equally true story-on the hot March day I finished collecting the data for my work, as I made my way home a welcome storm broke the sweltering heat, and the after-storm light bathed the landscape with a surrealistic golden glow. I intend the story of my interviewing journey, a journey that is both physical and metaphysical, to foreshadow the drama of the tragedies within the subjects' stories. I also intend this outer shell to highlight the temporal by situating the subjects' stories in a given time frame and anchoring them in a text to create a sense of continuity-something the subjects did not have as children. As well, I feel that once the stories of horror and trauma are no longer confined to the subject's unspoken memories but out on a page intended for public view, the subject and the reader, and I-as the interviewer and writer - can view and contemplate the care leavers' childhood trauma and hopefully gain a sense of what the experience felt like for them, and what it feels like to be a care-leaver.

Somewhat differently to Parker, in my book, in my more creative story (the inner framing narrative about my interviewing journey, and which I attempt to relate back to the subjects and their stories nevertheless) I try at times to step outside the interview situation and view the world through the lens of my own subjectivity. I hoped that this might provide the reader with information they can use as further points of reference and give 
added validity to the work. Within the framework of the interview process, I frequently interrupt the subjects' narrations with "smaller" stories that refer to life in general and tie back to the deeper meanings in what the subjects are saying. Some of these smaller stories are about my own experiences, present and past. I tried not to over-balance and go into competition with the subjects, but to write in a way that these smaller stories at once displace and frame and support the subjects' stories yet take second place to the subjects' stories, so that as soon as the subjects' conversations are reinstated their stories displace and reframe these smaller stories. My hope was that this would allow me to further make and highlight certain points, and also create in the work a sense of place, displacement, place and displacement that is in keeping with the subjects' experiences.

Somewhat differently to Parker also, in crafting I chose selections from the interview transcripts that I felt would balance the work, and moved these around. My wish was to create a readable story. Some critics might argue that this is in itself a fictionalising process. Others might say that fictionalisation begins the moment the writer begins crafting the literary docu-memoir from the interview transcripts. I feel that if one were to directly insert interview transcripts into the written work, without removing nearly all stops, starts, and jumping around natural in spoken conversations, and without moving selections of the edited verbatim interview material around to create a sense of flow and engender continuity on sometimes discontinuous memories, the reader would without a doubt find the written work too arduous to contemplate. But in the course of this "composing" I believe that I do not alter what the subjects have said in their interviews and transcripts, and I assign what has been said to the original speaker her- or himself so that, in the text, the subjects only ever say what they have actually said in real life. As well, to try and make it clear to the reader where the boundary lies between fiction and fact, and between verbatim and edited testimony, I use italics to indicate my actual interview questions as lifted from the transcript material, and I sandwich the edited and verbatim transcript material in between the more creative work which also includes snippets from the actual audio-taped conversations. I think of the literary docu-memoir form as I have tried to evolve it as a single car that has dual controls, and which requires two drivers-the writer, and the subject (a different subject in each of the stories) - who smoothly switch control of the vehicle backwards and forwards between them whilst the writer guides the car through the narrative.

With my work, because of my participants' histories as care-leavers, I felt that to confuse my subjects' identities as Parker does would be an act of condescension and betrayal. In an attempt to show each of my subjects as living people and to also keep the reader fully informed upfront as to 
what they are reading, I begin each story with a short introductory passage about the subject, and follow this with a photo of that subject which was taken by me with the subject's permission at the time of inter viewing, for use in my work. As children, most Forgotten Australians were dehumanised and stripped of their identity. Often their names were changed by those in charge, and most of these people's childhood records were either lost, or destroyed by the authorities. Rarely do these people have photos from their childhood. Very few photos were taken, but, quite often, any extant photos were destroyed by care-leavers themselves. Many careleavers experience flash-backs and horror in seeing images of themselves as children in care. In the main, all these people have to show that they existed as children are their memories. In my book, hopefully this double act of introduction and photo serves to show the subjects as people who actually exist, and helps the reader feel that they are meeting them, and refers the reader back to the text and the subjects' stories and what they have to say. Having said that in my work of literary docu-memoir I do not confuse the subjects' identities, I hasten to add that I do change names in a subject's story if specifically asked to do so by that subject. In this case I inform the reader as to what I have done upfront in the introduction to the subject's story. For instance, in keeping with Mick's wish to not be so openly identified, I begin his story with this introduction:

Mick Riley

For reasons of his own, Mick has asked that I not use his real surname or the real names of his family in this work. I will call him Mick 'Riley' [...]

In their photos to their stories all the subjects except Mick look directly into the camera. With Mick, in keeping with his desire to close the book on his past and "drive away" from it once he had told his story, I took his picture from the back as he literary drove away, and before I inserted it into the work I blurred the number plate on his motor bike so that, in the work, he could not be identified by name through that.

As the writer, I attempt to create "colour" to give the work a cinematic quality to highlight the effect of affect in the stories. Ivan Magrin-Chagnolleau posits that the use of "colour" in theatre and film can produce multiple effects that influence audience emotional response (MagrinChagnolleau 2013, 1-5). With literary works, all a writer has to create "colour" are words and the imagery suggested by contextual placement of these words, and perhaps images such as photographs that may appeal to the viewer on an affective level. In my work, in an attempt to achieve and heighten the effect of affect, I use words and imagery and photos in conjunction. I use black and white and grey tones for illustrations and photos that refer the reader to the subjects' past lives, and colour tones for photos that refer the reader to the subjects in the present day. As 
well, without touching the verbatim and edited transcript material in the work, in the more creative sections of the work-the creatively worked but nevertheless true story that frames the selections of transcript material into a whole-I try to marshal the affective thread in these people's stories and harness it to the imagery suggested in the framing narrative, and then braid this into the narrative thread that I weave throughout the work. As I see it, this is the creative element in my work of creative nonfiction. I will offer Geoff's three gardens as an illustration of what I have tried to do in this latter regard. Geoff's gardens really do exist, and are as I describe them in my book. One of these gardens has a strange fairy-tale atmosphere. In actuality, and so in my book, I find it fascinating and somewhat appealing, but equally, in real life and so in my literary docu-memoir, Geoff describes it as a "mess". Likewise, another of the gardens is a wasteland and has an eerie foreboding quality that does my head in, and the other, Geoff's narrow back garden, provides the viewer with sharp contrasts of deep shadow and unreal light when the late afternoon sun angles obliquely down. My intention is to show these gardens slant, as real but not real, and as somehow a reflection of Geoff's emotional experience or state. In much the same way, in the story of my visit, I am me and not me-I am the interviewer-writer in the work, and I am also the literary docu-memoirist in fact, and who in the story wears a fictional cloak.

\section{MYTHS}

It is my belief that literary docu-memoir occupies a territory that has immediate access to the real human story. It takes the emotional field to access the facts-history is to each of us what we experience at a personal and affective level. At the core of the literary docu-memoir is the myth that carries the meaning of what it is to be human. In this instance, the myth is the essential learning from the past. It is the way we each make sense of our experience and which is never just an experience, rather "truth"- a mixture of our lived life (the actual or factual experience), and our myth life (our memories and the way in which we each choose to interpret our story). All any of us really have that is truly our own is our story.

In Parker's Lighthouse, the people in the lighthouse community have similar experiences, and their myths are also fairly similar-they have a shared story in relation to life in the lighthouse community. In my study, I found that despite the similarities of my subjects' lived lives, the subjects' myths differed markedly one from the other. In this scenario, myth does not mean that in their stories the subjects' are telling lies, only that each 
person sees things differently to others. Truth is not an absolute, it is not a given, for each person it is different because truth is a relationship; it is relative to your circumstance. In a way, as does any other human being, each subject fictionalises their own story. Fictionalisation arises from a number of factors including how the subjects each remember and interpret their lived experience, and their actual words about that experience. As I see it, inherent in this mixture and intrinsic to it, is how the writer interprets the subjects' stories, and employs creative empathy in documenting the raw experience of others. ${ }^{12}$

For all that the subjects' personal myths differ there is a peculiarly strong thread of sameness in all the stories. This creates a space, wherein lies a myth of a different proportion-national mythology: that our Anglo-Australian society, that our Western societies, took care of their own, the children who were abandoned or neglected by their families. Underlying this myth is an undeniable fact that rises up to shatter the national mythologies: all the subjects' stories speak of cruelty to innocent children at the hands of adults, significant others, and in especial their "carers". As children, the care-leavers were not looked after by our Western societies in any way. Any childhood betrayed by their own society explodes the national mythologies - that of a society looking after its own. I feel that this is revealed not only at the factual level in the stories, but also on a deeper level to show the bones of the matter. This is the footprint that connects the care-leavers' stories to us as readers.

In my work of literary docu-memoir, I have tried to tell the subject's stories "true" as they would have me do. But I am still haunted by the thought that I have not done full justice to the subjects and their stories. I fear I may have missed something important in my crafting, and wonder if in trying to avoid certain dangers and pitfalls I may have created some new problems. I also am haunted by ethical questions: did I approach the task ethically, and did I manage to stay true to the facts to honour my contract with the reader, and also with the subjects to show their "truths"? In a fictionalised documentary, did I make it clear where the boundary lies between fiction and fact, and verbatim and edited testimony? There are also literary questions: As the researcher, how much should I appear as myself in the narrative? Did I use the powerful raw material to effect and write the work in such a way that the subjects came into vivid threedimensional life for the reader?

My primary aim in writing is similar to that of Parker: to create a literary space where the subjects could gain a literary voice, to show the reader lives about which little is known and help dispel possible misconceptions. As far as I know, in writing my literary docu-memoir, I have evolved a new way of writing lives, even though adapted from the form pioneered 
by Parker. It is my belief that such writing can show, as perhaps no other form can do, a complex picture of the care-leaver experience and the scars that these people carry, and what it means to be human. I also see that such writing can be applied to other lives that are little understood, to show the reader what it feels like to have lived an unusual life.

\section{WORKS CITED}

Ablon, Steven L. and Daniel Brown, Edward J. Khantzian, John E. Mack, eds. Human Feelings: Explorations in Affect Development and Meaning. Hillsdale, New Jersey USA: Analytic Press, 1993. Print.

Black Elk. Black Elk Speaks: Being the Life Story of a Holy Man of the Oglala Sioux as Told Through John G. Neihardt (Flaming Rainbow): Annotated by Raymond J. DeMaille; with Illustrations by Standing Bear. Albany, NY: Excelsior Editions, State U P., 2008. Print.

Cheney, Theodore. A. Rees. Writing Creative Nonfiction: Fiction Techniques for Crafting Great Nonfiction. Berkeley: Ten Speed Press, 2001. Print.

Couser, G. Thomas. Vulnerable Subjects: Ethics and Life Writing. Ithaca NY: Cornell U P. 2004. Print.

Couser, G. Thomas. Signifying Bodies: Disability in Contemporary Life Writing. Ann Arbor: U of Michigan Press, 2009. Print.

Couser, G. Thomas. Memoir: An Introduction. Oxford: Oxford U P, 2012. Print.

Ding, Loni. "Documemoir Visual Approach." In About Documemoir by Loni Ding. Center for Educational Telecommunications. "Documemoir." 1998 (pp. 1-5). Web. 4 Nov. 2012. http://www.cetel.org/docu.html.

Forché, Caroline, and Philip Gerard, eds. Writing Creative Nonfiction: Instruction and Insights from the teachers of the Associated Writing Programs. Cincinnati, Ohio: Story Press, 2001.

Magrin-Chagnolleau, Ivan. "The Use of Color in Theater and Film." Conference. Newcastleon-Tyne, England. 8-12 July, 2013. Address. Web. 6 July 2014. www.academia.edu/3522822.

Margulies, Alfred. "Empathy, Virtuality, and the Birth of Complex Emotional States." Eds. Ablon, Steven L. and Daniel Brown, Edward J. Khantzian, John E. Mack. Human Feelings: Explorations in Affect Development and Meaning. Hillsdale, New Jersey USA: Analytic Press, 1993: 181-202. Print.

Neihardt, John G. Preface 1932. Black Elk Speaks: Being the Life Story of a Holy Man of the Oglala Sioux as Told Through John G. Neihardt (Flaming Rainbow): Annotated by Raymond J DeMaille; with Illustrations by Standing Bear. Albany NY: Excelsior Editions, State U P., 2008. Print. http://library.ucsc.edu/reg-hist/oral-history-primer.

Parker, Tony. Lighthouse. London: Eland, 1975. Print.

Perl, Sondra, and Mimi Schwartz. Writing True. Boston: Houghton Miffin Co., 2006. Print.

Smith, Lyn. "Only Listen ... Some Reflections on Tony Parker's Methodology." Ed. Keith Soothill. Criminal Conversations: An Anthology of the Work of Tony Parker. Introduction by Terence Morris. London: Routledge, 1999: 243-254. Print.

Smith, Sidonie and Julia Watson. Reading Autobiography: A Guide for Interpreting Life Narratives. Minneapolis: U of Minnesota P, $2^{\text {nd }}$ ed., 2010. Print.

Soothill, Keith. ed. Criminal Conversations: an Anthology of the Work of Tony Parker. Introduction by Terence Morris. London: Routledge, 1999. Print.

Thompson, Paul."Tony Parker: Writer and Historian Interviewed by Paul Thompson." Oral History Vol. 22: No. 2. 25th Anniversary Issue (Autumn, 1994)). 64-73. Web. 3 Aug. 2010. http://www.jstor.org/stable/40179366. 
Wilson, Diane. Spirit Car: Journey to a Dakota Past. Minnesota: Minnesota Historical Press. 2006. Print.

\section{ABOUT THE AUTHOR}

Jo Parnell holds a PhD in English and Writing, from the University of Newcastle, Australia. She is a Conjoint Fellow to the School of Humanities and Social Science, and also a part-time reviewer on the editorial board of the journal Auto/ Fiction, and a volunteer research assistant to the Rare Book Collection, Cultural Collections Auchmuty Library, University of Newcastle, Australia. Professor Hugh Craig, formerly her principal supervisor, is her mentor.

Jo Parnell is an essayist, memoirist, literary docu-memoirist, and has published nationally, and internationally. Currently, apart from submitting journal articles and speaking at conferences on her subject, she is seeking a publisher for her work of literary docu-memoir, titled See Saw Margery Daw (which she wrote as a part of her doctoral dissertation), and for her memoir, The Carpet Child. As well, at present, she is writing a work of creative non-fiction with the working title of Journal of a Young Man at Sea, and is in the process of drafting a text book on how to write literary docu-memoir.

\section{NOTES}

1 As far as I am aware, other than for my own work, there is no existing research or definition of literary docu-memoir as such.

2 For a comprehensive discussion on biography see Smith, Sidonie, and Julia Watson. Reading Autobiography: A Guide for Interpreting Life Narratives. Minneapolis: U of Minnesota P, $2^{\text {nd }}$ ed., 2010.

3 Affective resonance, how we internally "mirror" - "see" and "feel"-those affective states that are those of some other, and relate to that person through unconscious recognition, is key to the process of empathy: see Margulies, Alfred. "Empathy, Virtuality, and the Birth of Complex Emotional States." Ed. Ablon, Steven L. and Daniel Brown, Edward J. Khantzian, John E. Mack. Human Feelings: Explorations in Affect Development and Meanin. Hillsdale, New Jersey USA: Analytic Press, 1993: 181-183.

4 Parker "always strove to put the reader in the picture, and became a very skilled pen-portraitist describing his informant in his or her setting": Smith, Lyn. "Only Listen ... Some reflections on Tony Parker's methodology." Ed. Keith Soothill. Criminal Conversations: An anthology of the work of Tony Parker. Introduction by Terence Morris. London: Routledge, 1999: 251

5 Cheney argues a writer's positioning: "creative nonfiction writers may well bring themselves into a story, either overtly or subtly, believing it only fair to let the reader gauge the writer's credibility and thus the accuracy of the facts presented." Cheney, Theodore. A. Rees. Writing Creative Nonfiction: Fiction Techniques for Crafting Great Nonfiction. Berkeley: Ten Speed Press, 2001: 197.

6 In a review of Parker's work John Banville once wrote: "he is a very cunning writer. By means of arrangement and pattern, rhythm and tone [...] he achieves an extraordinary narrative tension. He knows exactly where to place things, so the reader is carried along 
from one sly revelation to the next ... he is as little present [in his books] as is possible to be, but that does not mean he is off paring his finger nails" (qtd. in Smith 1999, "Only Listen ..."1999, 252).

7 Smith describes Parker as a man of strong personal principles, "determined to be faithful to the person and setting" and equally determined to adhere strictly "to his principle of confidentiality"; and she reveals that in keeping with his self-imposed ethics, together with his desire to be honest with his readers, Parker kept detailed resource books on each informants physical features and observable behaviours and characteristics, but when crafting his books he would change each informant's height, hair and eye colour, and "hone these pen-portraits to economic perfection" (Smith "Only Listen ..." 1999, 245-251).

8 Smith writes that Parker's methods and the new genre he invented "came under attack" from "members of criminological research establishments and academe"; his reply to his critics was, "This is what I want to do, and if it doesn't fit any neat methodology-no problem for me [....] I'm not appealing to scientists and academics. I'm trying to get through to your ordinary everyday reader who doesn't know anything about statistics and doesn't want to know" (Smith "Only Listen..." 1999, 252-253).

9 Idem.

10 Black Elk tells his story to Neihardt through an interpreter-his son, Ben-and in telling his story also tells the story of the Indian tribe to which he belongs. Couser names the work as an influential depiction of the Lakota culture but finds that Neihardt imposed his own agenda on the text. Neihardt was at pains to suppress any mention of Black Elk's and his relatives' conversion to Christianity and acculturation into European ways of life, as well as his own connections as a pastor of the church: see Couser, G. Thomas. Vulnerable Subjects: Ethics and Life Writing. Ithaca NY: Cornell U P, 2004: (42-43).

11 See Couser (2004), on the vulnerability of people such as, for one example, Black Elk. For further discussion on vulnerability, specifically on subjects who are created vulnerable through suffering some physical or mental disability or other anomaly, see: Couser, G. Thomas. Signifying bodies: disability in contemporary life writing. Ann Arbor: U of Michigan Press, 2009.

12 See Margulies on the subjective nature of what, for want of a better term, we call empathy: "Empathy is by its very nature projective [.... Our own experience, even if powerfully and incontrovertibly in resonance with the other, must remain our own experience of the other's experience. We can share with, but can never be, the other [.... We can only approximate another's experience from within the framework of our own" (Margulies 1993, 183). 